\title{
New Insights in Preterm Nutrition
}

\author{
Paola Roggero ${ }^{1,2, * \mathbb{C}}$, Nadia Liotto ${ }^{1}{ }^{\mathbb{D}}$, Camilla Menis ${ }^{1,2}$ and Fabio Mosca ${ }^{1,2}$ \\ 1 Neonatal Intensive Care Unit, Fondazione IRCCS Ca' Granda Ospedale Maggiore Policlinico, 20122 Milan, \\ Italy; nadia.liotto@policlinico.mi.it (N.L.); camilla.menis@gmail.com (C.M.); fabio.mosca@unimi.it (F.M.) \\ 2 Department of Clinical Sciences and Community Health, University of Milan, 20122 Milan, Italy \\ * Correspondence: paola.roggero@unimi.it
}

Received: 16 June 2020; Accepted: 17 June 2020; Published: 22 June 2020

check for updates

Nutrition of preterm infants has a crucial role in the promotion of organ's optimal growth and development [1-4].

In recent years, much has been researched, discussed and written on the ideal nutritional approach, suitable growth and the possible short- and long-term health consequences related to overor undernutrition and inappropriate growth [5].

Sir David Cuthbertson [6] emphasized that "we all owe our foetal life till parturition to the passage of the nutrients we require from the blood vessels of our mothers into our blood vessels as they traverse the chorionic villi in a close relation". Therefore, "intravenous feeding" is crucial in preterm infants who need parenteral nutrition for sustaining postnatal life, as "intrauterine feeding" ends abruptly with the clamping of the umbilical cord at birth. Preterm birth interrupts the physiological growth path of the foetus that occurs during the third trimester of pregnancy. At this stage, it is known that the foetus has a rapid growth phase that can hardly be maintained by the preterm infant due to changes in the environment related to birth. The environment to which preterm infants are exposed is very different from the maternal uterus and causes an increase in their energy expenditure due to the need to maintain thermal and metabolic homeostasis. Based on this scenario, it is crucial to define the nutritional management (in terms of intakes, timing and modalities) of preterm infants to ensure their adequate growth and development.

Important results have been achieved with regard to nutritional intake, both parenterally and enterally, in relation to gestational age and birth weight [7-9]. Based on the nutritional intake of the foetus in the womb, a consensus has been reached in recent decades regarding the need to guarantee "aggressive nutrition" to the preterm infant to mimic intrauterine growth and quality of growth and improve short- and long-term health outcomes [10]. Over the years, it has been observed that, despite an aggressive nutritional approach, neonatal growth did not reflect what was expected of a foetus of the same gestational age. Some authors [11] have investigated the possible causes of this postnatal growth retardation and have shown that, by analysing the actual cumulative nutrients administered, it was not always possible to achieve what was recommended due to the complexity of the daily management of preterm infants, especially if extremely preterm, due to the need to use nutritional access for other therapies. Therefore, it has been hypothesized that it may be inappropriate to compare preterm infant growth with the growth of their in utero counterparts. In this direction, the Intergrowth 21st study was designed, which suggested that the correct comparator for assessing the growth of preterm infants was a cohort of healthy preterm infants [12-15].

With this goal, the researchers of the Intergrowth 21st Consortium published preterm postnatal growth standards that allow to assess the growth of preterm infants until 64 weeks gestational age (6 months corrected age), the time at which they overlap, without the need for any adjustment, with the World Health Organization Child Growth Standards for term newborns [15]. In particular, this new approach for monitoring postnatal growth is more adequate in assessing the growth rates of preterm infants. In addition, this approach can consider "adequate" instead of "aggressive" nutritional management of preterm infants. 
The timing of nutritional intervention has been also defined. Indeed, since, with the premature birth, these infants interrupt their growth trajectory and they find themselves in a nutritional emergency. Therefore, any postnatal delay in undertaking an adequate nutritional intake creates a growth restriction over time. Consequently, there is a general consensus in early nutrition immediately after birth $[16,17]$.

Another issue that is scarcely discussed and difficult to study due to the complexity of the sample size necessary to achieve adequate study power, is related to the qualitative composition of the amino acid infusion mixtures used for parenteral nutrition of the premature infant. To date, there are no specific intravenous mixtures for preterm infants on the market, as the quality and quantity of the individual amino acids necessary for premature growth are unknown. Consequently, some proteins cannot be synthesized due to the lack of the quantity and quality of the amino acids necessary for preterm infants [18,19].

The transition phase from parenteral nutrition to enteral nutrition represents a challenge for neonatologists. This is a very vulnerable period, since the absorption of various nutrients from the intestinal lumen to the splanchnic district varies according to the type of amino acids. Therefore, it is crucial to carefully perform this transition to ensure adequate intake, mainly of protein, and consequently achieve adequate growth [20-22].

Regardless of parenteral nutrition, which is crucial for preterm infants in the first period of life, an increasingly central role of human milk is recognized not only for its nutritional value in terms of growth and quality of growth but also for its immune protection and for its role in modulating the microbiota, which plays a decisive role in the intestinal maturation of a highly vulnerable population such as severely preterm infants. Specifically, the metabolic capacity of the preterm gut microbiota may contribute to the production of energy and metabolites that influence gut maturation and metabolism [23-26].

Although human milk allows for the intake of functional nutrients that formulated milk cannot completely supply, it is unable to provide the protein/energy needs for preterm infants. For this reason, there is unanimous consensus on the need to fortify human milk, especially if donated. The fortification of human milk, as a supplement of macronutrients and micronutrients of bovine origin according to standard modalities, has evolved in recent decades due to the ever deeper knowledge of human milk composition and the need to guarantee the amounts of nutrients required by each infant. Indeed, through the introduction of the "adjustable" fortification mode, based on the evaluation of blood urea nitrogen, or of "targeted" fortification mode, based on the analysis of the micronutrient composition of human milk, it was possible to change the scenario of the fortification of human milk, resulting in improved growth outcomes [27].

Regarding body composition, the American Academy of Pediatrics, in 1977, recommended that body composition should replicate in utero body composition. Nevertheless, preterm infants at term-corrected age have altered body composition compared to term infants. Specifically, fat body mass in preterm infants at term-corrected age is significantly higher than that of full-term newborns [28]. In contrast, recently, it has been demonstrated that with increasing energy and protein intake during the hospital stay, higher fat-free mass at discharge was achieved, and fat-free mass was positively associated with neurodevelopmental outcomes at 12 and 24 months corrected age [29].

\section{Future Research}

The new concept of growth for preterm infants, based on growth trajectories of infants instead of foetuses, could have beneficial long-term effects on health. It would therefore be desirable that multi-centre randomized controlled trials be designed to explore the effect of early nutrition and growth on long-term health.

Author Contributions: P.R. wrote the editorial, N.L., C.M. and F.M. reviewed and revised the editorial. All authors have read and agreed to the published version of the manuscript.

Funding: This research received no external funding. 
Conflicts of Interest: The authors declare no conflict of interest.

\section{References}

1. Hay, W.W. Optimizing nutrition of the preterm infant. Zhongguo Dang Dai Er Ke Za Zhi 2017, 19, 1-21. [PubMed]

2. Cleminson, J.S.; Zalewski, S.P.; Embleton, N.D. Nutrition in the preterm infant: What's new? Curr. Opin. Clin. Nutr. Metab. Care 2016, 19, 220-225. [PubMed]

3. van Goudoever, J.B. Nutrition for Preterm Infants: 75 Years of History. Ann. Nutr. Metab. 2018, 72, $25-31$. [CrossRef] [PubMed]

4. Kumar, R.K.; Singhal, A.; Vaidya, U.; Banerjee, S.; Anwar, F.; Rao, S. Optimizing Nutrition in Preterm Low Birth Weight Infants-Consensus Summary. Front. Nutr. 2017, 26, 20. [CrossRef] [PubMed]

5. Power, V.A.; Spittle, A.J.; Lee, K.J.; Anderson, P.J.; Thompson, D.K.; Doyle, L.W.; Cheong, J.L.Y. Nutrition, Growth, Brain Volume, and Neurodevelopment in Very Preterm Children. J. Pediatr. 2019, 215, 50-55.e3. [CrossRef]

6. Dudrick, S.J.; Malkan, A.D. The History, Principles, and Practice of Parenteral Nutrition in Preterm Neonates in Nutrition for the Preterm Neonate. A clinical perspective; Patole, S., Ed.; Springer: Berlin/Heidelberg, Germany, 2013; pp. 193-213.

7. Darmaun, D.; Lapillonne, A.; Simeoni, U.; Picaud, J.C.; Rozé, J.C.; Saliba, E.; Bocquet, A.; Chouraqui, J.P.; Dupont, C.; Feillet, F.; et al. Parenteral nutrition for preterm infants: Issues and strategy. Arch. Pediatr. 2018, 25, 286-294. [CrossRef]

8. Neonatal Parenteral Nutrition Overview-NICE Pathways. Available online: https://pathways.nice.org.uk/ pathways/neonatal-parenteral-nutrition (accessed on 15 June 2020).

9. Agostoni, C.; Buonocore, G.; Carnielli, V.P.; De Curtis, M.; Darmaun, D.; Decsi, T.; Domellöf, M.; Embleton, N.D.; Fusch, C.; Genzel-Boroviczeny, O.; et al. ESPGHAN Committee on Nutrition. Enteral nutrient supply for preterm infants: Commentary from the European Society of Paediatric Gastroenterology, Hepatology and Nutrition Committee on Nutrition. J. Pediatr. Gastroenterol. Nutr. 2010, 50, 85-91. [CrossRef]

10. Hay, W.W., Jr. Aggressive Nutrition of the Preterm Infant. Curr. Pediatr. Rep. 2013. [CrossRef]

11. Embleton, N.E.; Pang, N.; Cooke, R.J. Postnatal Malnutrition and Growth Retardation: An Inevitable Consequence of Current Recommendations in Preterm Infants? Pediatrics 2001, 107, 270-273. [CrossRef]

12. Andrews, E.T.; Ashton, J.J.; Pearson, F.; Beattie, R.M.; Johnson, M.J. Early postnatal growth failure in preterm infants is not inevitable. Arch. Dis. Child. Fetal. Neonatal. Ed. 2019, 104, F235-F241. [CrossRef]

13. Pereira-da-Silva, L.; Virella, D.; Fusch, C. Nutritional Assessment in Preterm Infants: A Practical Approach in the NICU. Nutrients 2019, 11, 1999. [CrossRef] [PubMed]

14. Villar, J.; Giuliani, F.; Barros, F.; Roggero, P.; Coronado Zarco, I.A.; Rego, M.A.S.; Ochieng, R.; Gianni, M.L.; Rao, S.; Lambert, A.; et al. Monitoring the postnatal growth of preterm infants: A paradigm change. Pediatrics 2018, 141, e20172467. [CrossRef] [PubMed]

15. Villar, J.; Giuliani, F.; Bhutta, Z.A.; Bertino, E.; Ohuma, E.O.; Cheikh Ismail, L.; Barros, F.C.; Altman, D.G.; Victora, C.; Noble, J.A.; et al. International Fetal and Newborn Growth Consortium for the 21[st] Century [INTERGROWTH-21[st]] Postnatal growth standards for preterm infants: The Preterm Postnatal Follow-up Study of the INTERGROWTH- 21st Project. Lancet Glob. Health 2015, 3, e681-e691. [CrossRef]

16. Embleton, N.D. When should enteral feeds be started in preterm infants? Paediatr. Child. Health 2008, 18, 200-201. [CrossRef]

17. Thureen, P.T.; Hay, W.W., Jr. Early aggressive nutrition in preterm infants. Semin. Neonatol. 2001, 6, 403-415. [CrossRef]

18. van den Akker, C.H.P.; te Braake, F.W.J.; Rövekamp-Abels, W.W.; Van Goudoever, J.B. Quality of amino acid solutions for preterm infants. Pediatrics 2008, 121, 865-866. [CrossRef]

19. Vlaardingerbroek, H.; van Goudoever, J.B.; van den Akker, C.H.P. Initial nutritional management of the preterm infant. Early Hum. Dev. 2009, 85, 691-695. [CrossRef]

20. Liotto, N.; Amato, O.; Piemontese, P.; Menis, C.; Orsi, A.; Corti, M.G.; Colnaghi, M.; Cecchetti, V.; Pugni, L.; Mosca, F; et al. Protein Intakes during Weaning from Parenteral Nutrition Drive Growth Gain and Body Composition in Very Low Birth Weight Preterm Infants. Nutrients 2020, 12, 1298. [CrossRef] 
21. Miller, M.; Donda, A.; Bhutada, A.; Rastogi, S. Transitioning Preterm Infants From Parenteral Nutrition: A Comparison of 2 Protocols. JPEN 2017, 41, 1371-1379. [CrossRef]

22. Brennan, A.M.; Kiely, M.E.; Fenton, S.; Murphy, B.P. Standardized parenteral nutrition for the transition phase in preterm infants: A bag that fits. Nutrients 2018, 10, 170. [CrossRef]

23. Miller, J.; Tonkin, E.; Damarell, R.A.; McPhee, A.J.; Suganuma, M.; Suganuma, H.; Middleton, P.F.; Makrides, M.; Collins, C.T. A Systematic Review and Meta-Analysis of Human Milk Feeding and Morbidity in Very Low Birth Weight Infants. Nutrients 2018, 10, 707. [CrossRef] [PubMed]

24. Grases-Pintó, B.; Torres-Castro, P.; Abril-Gil, M.; Castell, M.; Rodríguez-Lagunas, M.J.; Pérez-Cano, F.J.; Franch, A. A Preterm Rat Model for Immunonutritional Studies. Nutrients 2019, 11, 999. [CrossRef] [PubMed]

25. Collado, M.C.; Cernada, M.; Neu, J.; Pérez-Martínez, G.; Gormaz, M.; Vento, M. Factors influencing gastrointestinal tract and microbiota immune interaction in preterm infants. Pediatr. Res. 2015, 77, 726-731. [CrossRef] [PubMed]

26. Henderickx, J.G.E.; Zwittink, R.D.; van Lingen, R.A.; Knol, J.; Belzer, C. The Preterm Gut Microbiota: An Inconspicuous Challenge in Nutritional Neonatal Care. Front. Cell. Infect. Microbiol. 2019, 8, 85. [CrossRef]

27. Arslanoglu, S.; Boquien, C.Y.; King, C.; Lamireau, D.; Tonetto, P.; Barnett, D.; Bertino, E.; Gaya, A.; Gebauer, C.; Grovslien, A.; et al. Fortification of Human Milk for Preterm Infants: Update and Recommendations of the European Milk Bank Association [EMBA] Working Group on Human Milk Fortification. Front. Pediatr. 2019, 7, 76. [CrossRef]

28. Roggero, P.; Giannì, M.L.; Amato, O.; Orsi, A.; Piemontese, P.; Morlacchi, L.; Mosca, F. Is term newborn body composition being achieved postnatally in preterm infants? Early Hum. Dev. 2009, 85, 349-352. [CrossRef]

29. Ramel, S.E.; Haapala, J.; Super, J.; Boys, C.; Demerath, E.W. Nutrition, Illness and Body Composition in Very Low Birth Weight Preterm Infants: Implications for Nutritional Management and Neurocognitive Outcomes. Nutrients 2020, 12, 145. [CrossRef]

(C) 2020 by the authors. Licensee MDPI, Basel, Switzerland. This article is an open access article distributed under the terms and conditions of the Creative Commons Attribution (CC BY) license (http://creativecommons.org/licenses/by/4.0/). 